\title{
THE BANKING UNION IS 5 YEARS OLD Political goals, economic theories, practical results
}

\section{Krisztián Németh ${ }^{1}$}

The Banking Union, more specifically its first pillar, the single European banking supervision was established in November 2014. In my study, I aim to assess the operation of the Banking Union to date in the light of three considerations: Firstly, I examine the economic policy goals for the achievement of which the Banking Union was set up. Secondly, I introduce the economic theories which throw light on the mechanisms through which the Banking Union can promote the achievement of these goals. Finally, drawing on the experience gained throughout the organization's almost 5-year-long history, I try to present to what extent the Banking Union has been able to meet the expectations. In conclusion, I consider the pros and cons of Hungary's close cooperation with the Banking Union.

JEL codes: G21, G28

Keywords: Banking Union, banking supervision, European Union, resolution

\section{NEED FOR THE BANKING UNION}

The need for the establishment of the Banking Union was laid down by the Declaration issued at the Euro Summit on 29 June 2012 (European Council 2014). The Declaration reflects that the major problem for European legislators was the management of European sovereign crises in 2012. Namely, the "vicious circle between banks and government budgets had to be broken". According to the Declaration, this goal could be achieved by means of the Banking Union.

It is no coincidence that the European Union was looking for a solution to break this vicious circle in 2012. By that time, we had already witnessed the first waves of the crisis and the acceptance of the first two bail-out packages. It is important to see that despite the fact that it was a sovereign crisis, which refers to the liquidity of the government budget, the Greek and the European banking systems were also deeply affected, as most government securities issued by the Greek

1 Krisztián Németh is a teacher and advisor at the International Training Centre for Bankers. 
state were owned by foreign investors, mainly foreign banks. Based on the above, the mechanism of the vicious circle is already visible: banks tend to keep a significant part of their assets in domestic or foreign government securities. Consequently, the insolvency of sovereign participants may result in considerable loss for the banking system, as well. If such losses lead to the insolvency of certain banks, again the sovereign party has to decide whether to recapitalise the given bank or let it go bankrupt. By choosing the latter, the crisis may spread to other institutions of the banking system, as well. However, in the case of recapitalisation, the fiscal burden has to be considered, as it increases government debt and, through this, the likelihood of a sovereign crisis. At this point, the circle is closed: a sovereign crisis might bring about a banking crisis, which may aggravate the sovereign crisis.

Within the European Union, in addition to preventing unfavourable processes between government budgets and the banking system, a complex banking union also serves several other purposes, such as:

- If regulation and supervision go beyond national frameworks, internationalised banks/banking groups can be more effectively supervised and regulated. One reason for this is the more efficient flow of supervisory information (Darvas-Wolf, 2013).

- In this way, consistency is created in terms of supervisory methods.

- A single market, including a single money market, requires integrated supervision. Otherwise, differences in supervision will distort the decisions of market participants.

- Certain theories (e.g. the revolving door theory) back up that supervision can be more effective at international level than at national or small state-level.

- Within the monetary union, the European Central Bank (ECB) acts as the lender of last resort. During the crisis, the ECB had to face an additional risk: it had to ensure the liquidity of the banks of the Eurozone without having supervisory control over them (Hüttle-Schoenmaker, 2016).

\section{THE PILLARS OF THE BANKING UNION - THE REALISATION OF THE INTENTION}

Being a member of the Banking Union is compulsory for all member states of the Eurozone. At the same time, the EU Member States which are outside the monetary union have the right to decide whether they wish to be involved (opt in/opt out).

The Banking Union consists of $3+1$ pillars: 


\subsection{Single Supervisory Mechanism - SSM}

The SSM became operational in November 2014. The supranational supervisory powers were assigned to the European Central Bank (ECB), therefore it acts as a prudential supervisory body, in cooperation with national authorities. In the Banking Union, about 6000 institutions have to be supervised (Kisgergely-Szombati, 2014). The institutions qualified as significant are directly supervised by the ECB. Currently, based on the official website of the ECB, there are 117 significant institutions, which cover approximately $82 \%$ of the assets of the Eurozone's banks. ${ }^{2}$ Each significant institution is supervised by a joint supervisory team. The joint supervisory team provides a forum that is the main embodiment of the cooperation between national supervisory authorities and the ECB. The members of the joint supervisory team include the employees of the ECB as well as the employees of the supervisory authorities of those member states in which the supervised institution carries out substantial activities. ${ }^{3}$

Banks which are not qualified as significant are indirectly supervised by the ECB through national supervisory authorities.

\subsection{Single Resolution Mechanism - SRM}

The institutions supervised by the SSM fall into the scope of the Single Resolution Mechanism. The fundamental objective of the SRM is to burden taxpayers to the least possible extent in the case of a given institution's bankruptcy or near bankruptcy. The Single Resolution Mechanism consists of two additional institutions:

- The Single Resolution Board (SRB) is the central resolution body of the Banking Union, which, together with national resolution authorities, constitutes the SRM system. The SRB is an independent EU agency managing the Single Resolution Fund.

- The Single Resolution Fund (SRF), which can be used during the resolution proceedings, is a fund managed by the SRB. The rules on the establishment and expected size of the Single Resolution Fund are laid down in Regulation (EU) No. 806/2014: within 8 years after its establishment, the fund shall accumulate an amount that covers $1 \%$ of the deposits of the institutions.

2 https://www.bankingsupervision.europa.eu/about/thessm/html/index.hu.html

3 https:/www.bankingsupervision.europa.eu/banking/approach/jst/html/index.en.html

4 https://ec.europa.eu/info/business-economy-euro/banking-and-finance/banking-union/singleresolution-mechanism_en 


\subsection{Single Rulebook}

The Banking Union's spirit and operation are based on the Single Rulebook. On the other hand, the Single Rulebook differs from other pillars in the sense that it is compulsory not only in the Banking Union, but also in all Member States of the European Union. The single European regulation system is an important step towards the establishment of a truly integrated money market: it is an effective instrument against the effect of fragmented regulation that distorts competition and allocation, as well as against regulatory arbitrage.

\subsection{European Deposit Insurance Scheme - EDIS}

Currently, the single European Deposit Insurance Scheme is still a non-active pillar of the Banking Union. Its establishment is subject to discussion. The European Commission made a proposal for the establishment of a single deposit insurance scheme in November 2015 (European Commission, 2015).

At national level, deposit insurance poses problems similar to national-level resolution: the bankruptcy of a larger local institution places a considerable burden on both the national resolution fund and the national deposit insurance fund. In the event of any doubt as to whether the two institutions are able to carry out their activity in case of the bankruptcy of any of the local banks, even that of the largest local bank, distrust is evoked in the entire financial system.

\section{MECHANISM OF ACTION: HOW DOES THE BANKING UNION SERVE THE ACHIEVEMENT OF THE GOALS PURSUED?}

\subsection{Breaking the vicious circle between the government budget and the banking system}

In addition to the simple mechanism of action of the vicious circle described above, Gerlach et al. (2010) draw attention to a further consideration: the banking system represents extra cost for the government budget not only in the extreme situation of the recapitalization but also prior to that, as the markets price in the yields of government securities the costs of a potential bank bail-out. The main conclusion drawn by Gerlach et al. (2010) is that the government security spread reacts more intensely to the increase in aggregate risk in those countries where:

- the size of the banking system is significant and

- the banking system operates with high leverage. 
The two aforementioned aspects are related to the two components of the expected costs of bank bail-out: the amount of the costs of a potential bank bail-out and the probability of a banking crisis.

The resolution mechanism of the Banking Union gives an answer to the first point: it raises the bail-out of banks to the level of the EU. As a result, the fiscal burden on member states which have a considerable banking system compared to their size, arising from a potential banking crisis is reduced.

\subsection{The promotion of the functions of monetary policy}

Based on Chapter 3.1, the differences between the banking systems of various countries strengthen the phenomenon of diverging yield curves within the monetary union. At the same time, in the monetary union, there is only one base rate, by which only one yield curve (mainly the short end of it) can be effectively influenced.

The most obvious response to diverging yields is closer economic integration. The aim of the Banking Union is to promote such closer integration by establishing joint banking supervision and crisis management. Realistically, the following can be expected from the uniformly strict regulation, the independent, professional supervision and the EU-level bank resolution: On the one hand, the differences between banking systems should be reduced. On the other hand, despite not being able to eliminate differences completely, the different risks should be reflected by the financing costs of sovereign debts to a lesser extent. Based on the above, the indirect goal of the Banking Union can be the promotion of the effectiveness of common monetary policy, as well (Kisgergely-Szombati, 2014).

\subsection{Supervision of higher quality}

According to Darvas-Wolff (2013), one of the advantages of the SSM is the free flow of supervisory information. It is the supervision of international banks that this factor makes especially efficient. Without the Banking Union, subsidiary banks belonging to the same banking group, but operating in different countries would be under the supervision of different national supervisory authorities. A given national supervisory authority might take its decisions without having an overall picture of the operation of the entire banking group.

In addition, Darvas-Wolff (2013) emphasises that in the case of an internationalised banking system which is supervised (or, in certain cases, resolved) by separate national authorities, a kind of coordination problem necessarily arises. The coordination problem is the following: when a national authority is considering 
the costs and benefits of a supervisory measure (e.g. bank bail-out), it takes into account only the effect of the domestic benefits, i.e. the external effects of the measure, which can only be felt abroad, are ignored. As a result, at the level of the EU, the supervisory measure is carried out at suboptimal level. According to this approach, the establishment of the Banking Union is the internalisation of the costs and benefits of supervisory/resolution measures at EU level, which results in taking optimal supervisory decisions in the whole EU.

\subsection{Supervisory rigour and leniency at different levels of locality}

A study by Agarwal et al. (2012) proves by regression methodology that in the United States, federal supervisory authorities tend to act in stricter way than the authorities of the Member States. In the light of the above, the following conclusion can be drawn: the higher level banking supervision works, the less supervising authorities tend to be permissive or, in certain cases, too lenient. In other words, the local character of the operation of supervisory authorities predisposes them to leniency.

A theoretical explanation for this phenomenon is, inter alia, the so-called capture theory. According to capture theory, the primary aim of regulation or supervision is to ensure the uninterrupted operation of incumbent companies rather than correcting market imperfections (Viscusi-Vernon-Harrington, 2000). I suppose that raising supervision to the level of banking union would weaken the ability of the supervised institutions to control (capture) the authority. A bank that is significant in a Member State can exert stronger influence on its own national authority than on the ECB. Therefore, the Banking Union can effectively reduce the chance of capturing supervision.

The revolving door theory also supports that the locality level of supervision my affect the rigour of supervision. The revolving door phenomenon refers to a situation in which people working in the regulatory, supervisory or other public sector find a job in the private sector, taking advantage of the experience gained and the professional network established in their position. In terms of banking supervision, this phenomenon is especially harmful if the given people fulfil their supervisory duties to land a well-paid job at any of the supervised institutions in the future. Based on the above, it is clear that the revolving door phenomenon may ease the rigour and decrease the quality of supervision. If we accept the hypothesis that such a relationship is easier to establish if both the bank and the supervisory authority operate at national level, a Banking Union-level supervision may weaken the revolving door phenomenon to some extent. 


\subsection{The financial trilemma and the Banking Union}

Schoenmaker (2011) draws attention to an impossible trinity. In his article, in the framework of a game theory model, he describes the three economic policy goals which, in his view, cannot be achieved simultaneously:

- financial stability;

- internationalised banking system;

- national financial supervisory policy.

According to this approach, the Banking Union is a response to the financial trilemma. Based on the message of the Banking Union, in accordance with European values, the single market and the internationalised banking system cannot be forgone. Consistent with reason, financial stability has to be retained, therefore it is the national-level supervisory policy that has to be forgone.

\subsection{Supervisory reputation}

In the Single Supervisory Mechanism controlled by the ECB, supervisory reputation itself represents a value. Even Kisgergely-Szombati's study (2014), which was published by the National Bank of Hungary, acknowledges that the ECB's reputation exceeds that of the National Bank of Hungary. If excess reputation really exists, it creases confidence in the supervised institutions, reducing their financing costs.

Regarding the role of reputation, it is worth examining a question raised by Mérö-Piroska (2017) about why Bulgaria and Romania expressed their intention to join the Banking Union in the Eastern-Central European region. At the same time, why did the Czech Republic, Poland and Hungary refrain from doing the same? According to Mérö-Piroska (2017), we should compare to what extent the individual states are able to maintain the stability of their own financial systems. In terms of this ability, Bulgaria and Romania's performance was definitely worse than that of the other three countries. In the light of the above, the import of the credibility of the Banking Union's supervision may provide the highest added value for Romania and Bulgaria.

\subsection{The role of the Banking Union in the management of regulatory/supervisory arbitrage}

In the banking sector, regulatory or supervisory arbitrage means that within a bank or a banking group certain activities are moved in order to make them subject to less rigorous or other type of regulation/supervision. Mainly international 
banks have the opportunity to apply this method, because they take advantage of the supervisory and regulatory fragmentation between certain countries. From the point of view of the regulator, the phenomenon is definitely harmful, as the banks can only reduce their supervisory/regulatory burden by not reducing their risks at all. The phenomenon is problematic not only because of the fact that the individual institutions might remain without appropriate supervision. There is another serious problem, as well: the banks' escape towards more relaxed supervision has repercussions on the behaviour of authorities, because there might be a competition among the supervisory authorities of different countries ("race to the bottom") to relax supervision (Nouy, 2017).

How can banks use supervisory arbitrage in practice? Mainly by creating a flexible organisational structure, adjusting it to the regulatory environment. Regarding the organisational structure of international banks, the main question is whether they provide their services in a given country through a subsidiary or a branch. The subsidiary is considered to be an independent legal entity, which is supervised by the authority of the country where it operates. By contrast, the branch is part of the parent company, therefore it is not an independent legal entity. Internationally, it is the means of cross-border provision of services. Legally, it is part of the parent company, therefore it is supervised by the competent authority of the country in which the parent company is based.

\section{CASE STUDIES ON THE OPERATION OF THE BANKING UNION}

\subsection{Nordea}

Nordea Bank (Nordea Bank Abp.) is the largest bank of the Scandinavian region. In 2017, it was still on the G-SIB list, which means that it was considered to be a bank of globally significant size. Accordingly, it had to meet stricter regulatory requirements. In December 2017, its balance sheet total amounted to EUR 581 billion.

On 6 September 2017, the Board of Directors of Nordea initiated the relocation of the registered office of the parent company from Stockholm (Sweden) to Helsinki (Finland). Regarding the Banking Union, the relocation of the registered office is important because Sweden is not a member of the Banking Union. Moreover, Sweden declared that it would not join the union. As opposed to Sweden, Finland, as a member of the Eurozone, is automatically involved in the Banking Union. Consequently, the relocation of the registered office also means that Nordea is to change its supervisory authority, as well: instead of the Swedish Financial Supervisory Authority (Finansinspektionen), it will be supervised by the Banking Union, which involves direct supervision by the ECB owing to the size of the bank. 
In March 2018, Nordea issued a statement, summarising its arguments for the relocation of its registered office: 5

- Nordea is an international bank whose balance sheet total is the double of the GDP of any Scandinavian country. Considering its size, Nordea aims to be supervised by a sufficiently strong institution. As far as the strength of supervision is concerned, Nordea definitely considers ECB to be the best option.

- Out of the four potential headquarters, only Finland is a member of the Banking Union.

- Relocation to Finland and the Banking Union enables Nordea to get into the same supervisory environment as its largest European competitors. Therefore, the competition among them is not distorted by differences in supervision. As a result, the operating environment of the bank becomes more predictable. Of course, there may be arguments for the relocation of the registered office which are not mentioned in the statement by Nordea referred to above. In any case, we should emphasise the debate about the Swedish Stability Fund: the Swedish government increased the contribution to be paid by credit institutions to the fund, which would have been a considerable burden on Nordea. As a response, Nordea threatened the Swedish government to relocate its registered office. On 6 September 2017, the Board of Directors of Nordea initiated the relocation of the bank's registered office, indeed, which officially took place on 1 October 2018. The new registered office of the bank is located in Helsinki. ${ }^{6}$ According to Nordea's own estimates, it can save EUR 1.1-1.3 billion in present value due to the relocation of its registered office. In fact, the saving is partly the result of the avoidance of the increased contribution to be paid into the Swedish Stability Fund.

It is observable that the differences in supervisory and regulatory rigour are important components of the motivation behind the relocation of the registered office. The banking requirements laid down in the regulations in Finland or the Banking Union are less rigorous than in Sweden in the areas of resolution funds, deposit insurance as well as taxation. Based on the above, there is the possibility of regulatory arbitrage even behind Nordea's decision, in spite of the fact that other banking union-specific aspects may play a role, as well: a considerable resolution fund or the same regulatory environment as that of the European competitors.

5 https://www.nordea.com/en/press-and-news/news-and-press-releases/news-group/2018/why-wepropose-to-move-into-the-banking-union.html

6 https://www.nordea.com/en/press-and-news/news-and-press-releases/press-releases/2018/10-o1o7h30-nordeas-re-domiciliation-is-completed.html

7 https://www.nordea.com/Images/36-238152/Information\%2oregarding\%2othe\%2oproposed\%2O re-domiciliation\%2oto\%2oFinland.pdf 
Press reports tend to present the increase of Swedish resolution fees as the direct cause of the relocation of the bank's registered office. In my opinion, the decision had been taken earlier, before the government's announcement. This assumption is supported by the fact that Nordea started significant organisational restructuring in 2016 ${ }^{8}$ : Before 2016, the Stockholm-based bank had provided its services through its subsidiaries in Denmark, Norway and Finland. The most important move of the restructuring of 2016 was that the subsidiary banks were turned into branches. As they had been part of the parent company in Stockholm earlier, they were supervised by the Swedish authority. As if this move had been the preparation of the subsequent relocation of the registered office: as a result of converting these subsidiaries into branches, the whole Scandinavian line of business of Nordea was concentrated in the hands of the Swedish parent company, the entire organisation could be moved to Finland, under the supervision of the ECB by simply relocating the bank's registered office in 2018 .

\subsection{ABLV}

ABLV Bank (ABLV Bank, AS) was the third largest bank in Latvia. As it was associated with money laundering in February 2018, the bank lost the confidence of its clients, its operation became impossible and it initiated bankruptcy proceeding against itself. The case study is relevant, as Latvia is a member of the Eurozone and the Banking Union. In view of the above, it was already the institutional system of the Banking Union, i.e. the SRB that made a decision on the necessity of the resolution of the bank.

Based on its assets on 30 September 2017, ABLV Bank was the third largest bank in Latvia. With its assets of EUR 3649 million, ABLV had a market share of about $13 \%$ in Latvia. ${ }^{9}$ Due to its size, it was directly supervised by the ECB. The significance of ABLV is reflected by the fact that it was one of the six "other systemically important institutions" (O-SIIs) in the Latvian banking system. Moreover, the supervisory authority prescribed the highest O-SII capital buffer of $2 \%$ for the bank. It had already become clear by May 2016 that the operation of the bank was not totally in order. The Latvian supervisory authority (Financial and Capital Markets Commission - FCMC) imposed a fine of EUR 3 million on ABLV and condemned the Board Member in charge of anti-money laundering activity. ${ }^{10}$ The

8 https://www.nordea.com/en/press-and-news/news-and-press-releases/news-group/2018/why-wepropose-to-move-into-the-banking-union.html

9 https://www.financelatvia.eu/wp-content/uploads/2018/12/Banks-Statistics-Q3-2017.pdf

$10 \mathrm{https} / /$ www.bankingsupervision.europa.eu/press/pr/date/2018/html/ssm.pr18o224.en.html 
bank launched an internal audit, while the FCMC ordered the bank to strengthen its internal control. However, further administrative measures were not taken.

The crisis of ABLV started on 13 February 2018, when FinCEN (Financial Crimes Enforcement Network) issued a statement according to which ABLV Bank was involved in money laundering activity as a primary actor ${ }^{11}$. FinCEN is the U.S. Department of the Treasury's bureau in charge of combating financial crimes. According to the charge of FinCEN, money laundering was institutionalised as part of the business model within the bank by the bank's management, shareholders and employees. In order to be able to pursue money laundering activity, they deliberately weakened internal controls, especially related to the accounts of shell companies. According to FinCEN, the bank consciously avoided the application of risk controls of appropriate quality, such as KYC (know your customer) and CDD (customer due diligence) processes. Based on the charges, nor did the bank shy away from corruption to hide its illegal activity (FinCEN 2018). On the other hand, it should be mentioned that Ernests Bernis, CEO of ABLV, denied the charges by FinCEN. ${ }^{12}$

After the publication of FinCEN's statement, the clients started to withdraw their deposits in a panicky manner. Furthermore, the bank was unable to obtain USD funds, therefore it could not fulfil its expiring liabilities denominated in USD within a short period of time. The ECB directed the FCMC to declare a bank moratorium, giving time for ABLV's management to stabilise the situation. However, stabilisation was not successful. On 23 February 2018, the ECB took a decision, declaring ABLV Bank "fail or likely to fail". Based on the justification, ABLV's liquidity had deteriorated to such an extent that it would not be able to fulfil its expiring liabilities and deal with the extreme outflow of resources generated by the stress.

By declaring ABLV bankrupt, the ECB empowered the SRB to take a decision. The resolution authority had to consider whether the resolution of the bank was justifiable. Based on the ECB's decision, the first condition out of the three conditions of resolution has been fulfilled, which means that ABLV is insolvent or it can be presumed that it will become insolvent.

The SRB has examined whether there is any other supervisory or private sector measure that could make the bank's bankruptcy avoidable. The SRB answered in the negative, emphasising that none of the liquidity measures from the bank's

11 "Money laundering is an illegal service (often provided in the economic sector) which converts some kind of "dirty money" (deriving from a crime committed earlier) to money that comes from seemingly legal source.” (Gál 2007)

12 http://leta.lv/eng/home/important/133EDo33-14AA-B89E-4A69-oBF8B494195A/ 
2017 recovery plan can be successfully implemented. Therefore, the second condition of resolution was fulfilled, as well.

The third condition of resolution is whether the resolution is justifiable by public interest. However, in the case of ABLV, the SRB decided that resolution cannot be justified by public interest, therefore it did not take place. Based on the explanation provided by the SRB, resolution is not justifiable by public interest, $\mathrm{as}^{13}$ :

- the services provided by the ABLV are not critical for the financial system;

- according to the SRB, the bankruptcy of the bank is unlikely to erode financial stability either in Latvia, or in any other Member State of the European Union;

- ABLV's connections with other institutions and its embeddedness in the financial system are insignificant.

In the light of these developments, on 26 February 2018, the shareholders of ABLV decided to initiate the liquidation of the bank. On 5 March, the liquidation plan was submitted to the supervisory authority. On 12 June, the FCMC approved of the launch of the liquidation proceedings. Based on the FCMC's approval, the management is to be replaced by liquidators. ${ }^{14}$

\subsubsection{The assessment of the ABLV case}

In her statement, Danièle Nouy, Chair of the Supervisory Board of the SRB, emphasised that at the time when the SSM was established, the member states themselves decided to keep the fight against money laundering within national competence, therefore the Single Supervisory Mechanism shall not be liable. ${ }^{.5}$ The ABLV case and Danièle Nouy's statement draw attention to a contradiction in the operation of the SSM. The definition of conduct risk also covers money laundering as inappropriate provision of services which results in potential financial loss for the bank. The definition of money laundering as conduct risk is also verified by a speech published by Robert Taylor on 28 November 2014. Robert Taylor, as one of the leaders of the financial supervisory authority of the United Kingdom (Financial Conduct Authority - FCA), highlighted money laundering as a major component of conduct risk, which may cause substantial damage to institutions through the erosion of confidence in banks. ${ }^{16}$

\footnotetext{
13 https://srb.europa.eu/sites/srbsite/files/20180223-summary_decision_-_latvia.pdf

14 http://www.fktk.lv/en/media-room/press-releases/7085-fcmc-permits-ablv-bank-as-toimplement-voluntary-liquidation-plan-under-control-of-fcmc.html

15 https://www.bankingsupervision.europa.eu/press/pr/date/2018/html/ssm.pr18o222.en.html

16 https://www.fca.org.uk/news/speeches/conduct-risk-briefing
} 
ABLV was directly supervised by the ECB. Consequently, the ICAAP process at ABLV had to be reviewed by the ECB in the framework of the SREP process. As the Internal Capital Adequacy Assessment is fully comprehensive, it should have included conduct risk as one of the important components of operational risk. Special attention was drawn to the materiality of conduct risk by the fact that the FCMC already fined ABLV for money laundering in 2016. Based on Danièle Nouy's statement, if the ECB is not allowed to examine the factual situation of money laundering, it cannot be involved in the SREP process as a full supervisory authority either, as money laundering has to be included in the risk inventory of ICAAP where applicable. In the light of this, it needs to be assessed by the supervisory authority, as well.

The SRB is assumed to have been in a very difficult situation when it had to decide on the resolution of ABLV. Based on the above-mentioned statement by the SRB, no public interest exists, as it is not assumed that the bankruptcy of ABLV will considerably erode financial stability, and the bank's connections with other institutions and financial embeddedness are not significant enough either. On the other hand, this conclusion contradicts several facts I mentioned in connection with the case study:

- ABLV is the third largest bank in Latvia.

- The supervisory authority classified ABLV as an O-SII institution and, what is more, prescribed the highest O-SII capital buffer of $2 \%$ for the bank.

By taking its decision, the SRB took the risk that the operation of the Banking Union might seem to be inconsistent. The Banking Union does not intend to save a bank, considered as important earlier, because it does not regard it as significant enough to threaten financial stability. It may give rise to criticism according to which a large bank from a small country is not considered to be significant enough in Frankfurt to deserve the use of the resolution fund if needed. In view of this smaller countries are disadvantaged within the Banking Union. However, I presume that the SRB would have been more heavily criticised if they had resolved ABLV. Using the common resolution fund to save a bank involved in money laundering and its clients with uncertain background would have been very anomalous. Ultimately, the SRB had to consider which of the two bad options would be less harmful for the reputation of the Banking Union. 


\section{THE BANKING UNION IN HUNGARY: PROS AND CONS}

In this chapter, I examine the Banking Union in terms of the Hungarian financial system. In my assessment, I intensely rely on the previous chapters, therefore this part of the study can be regarded as a summary.

As Hungary is not a member of the monetary union, it can decide whether it wants to join the Banking Union or not. Member States outside the monetary union can join the Banking Union in the framework of so-called close cooperation $^{17}$. However, it should be noted that none of the countries have concluded a close cooperation agreement yet, though Romania, Bulgaria and Denmark have expressed their intention to join the Banking Union or at least their interest in the organisation. Currently, Hungary is pursuing a strategy of "waiting".

\subsection{Arguments for Hungary's accession}

According to Kisgergely-Szombati (2014), the most important argument for joining the Banking Union is the reputation of the ECB. The two authors stress that the professional reputation of the ECB and the SSM (through the ECB) exceeds that of the national authorities, including the National Bank of Hungary. Accession to the Banking Union would increase the credibility of the national supervisory authority in the eyes of investors, especially foreign investors. Under more credible supervision, the economic operators financing the banks, being aware of lower risks, expect lower yields from their investments, thus reducing the financing costs of the banking system. Kisgergely-Szombati (2014) also mention that the ECB, as a supervisory authority, could view the national banking system free from various influences, which would strengthen credibility, as well. Their statement is in line with the capture theory described in Chapter 3.4. as well as the revolving door theory.

In addition to the Banking Union, we may use the structure of the domestic banking system as an argument, as well. Foreign share can be considered high both in Hungary and the countries of the region (Mérö-Piroska, 2017). In spite of the fact that the percentage of foreign ownership has decreased since the end of the crisis, it was $50.1 \%$ at the end of $2018 .{ }^{18}$ Most foreign banks operate as subsidiaries, therefore they are supervised by the National Bank of Hungary. Due to joining the Banking Union, the subsidiaries of large foreign banks would be subject to the direct group-level supervision of the ECB. In the framework of group-level

\footnotetext{
17 https://www.consilium.europa.eu/hu/policies/banking-union/

$18 \mathrm{https} / /$ www.mnb.hu/felugyelet/idosorok/i-penz-es-hitelpiaci-szervezetek/hitelintezetek
} 
supervision, in accordance with Chapter 3.3, the flow of supervisory information is more efficient than in a situation when the members of the group are supervised by different authorities. Regarding subsidiary banks of foreign interest, it would also be advantageous that the accession would remove the additional burden of compliance with double supervisory requirements. Currently, under group-level supervision, these banks have to comply with the requirements set by the ECB, and, under the supervision of the national authority, with the requirements set by the National Bank of Hungary.

Another advantage of joining the Banking Union is access to the resolution fund of considerable size. The SRF's target level of EUR 55 billion is imposing: it exceeds the balance sheet total of the largest Hungarian bank (OTP) and is about 10 times larger than its equity. By contrast, the target level of the domestic resolution fund is insignificant (HUF 9o billion): just half percent of OTP's balance sheet total and less than $5 \%$ of its own equity. ${ }^{19}$ Comparison with the balance sheet and earnings data throws light on the fact that the national resolution fund could be sufficient to save mainly smaller institutions. Access to the European-level resolution fund would be a substantive value for larger domestic institutions.

Another argument for accession is that the decision would not be definitive and irrevocable. Member states in close cooperation are entitled to leave the union immediately if:

They do not agree with any of the proposals of the Board of Supervisors. They inform the Governing Council of this fact, but the latter accepts the proposal.

The Governing Council rejects any of the proposals of the Board of Supervisors. They do not agree with the rejection, inform the Governing Council of this fact, but the Governing Council is not willing to charge its previous negative decision (Kisgergely-Szombati, 2014).

\subsection{Arguments against Hungary's accession}

The arguments presented in the previous sub-chapter can be put into a different perspective. It is reasonable to assume that the lobbying power and "capturing" ability of domestic banks are not enough for European-level banking supervision. At the same time, it does not mean that European-level banking groups could not exert pressure on the national banking supervisory authority. Based on the above, the risk exists that the only change the accession to the Banking Union would

19 https://www.otpbank.hu/portal/hu/IR_Kiemelt_adatok 
bring about would be that instead of the national institutions, their international competitors would be better at enforcing their interests.

Regarding resolution decisions taken by the Banking Union, Andrea Enria's statement about the dual interpretation of public interest may be a warning sign. ${ }^{20}$ A situation in which public interest is interpreted in a different manner at European level (SRB) and at the level of the Member States may arise easily. The insolvency of two Italian banks, Banca Popolare di Vicenza and Veneto Banca, drew attention to this risk in the summer of 2017: the SRB declared that the resolution of the insolvent banks was not justified by public interest. On the other hand, the Italian state conducted quasi resolution, using a considerable amount of government funds, which gives rise to doubts as to whether the Banking Union promotes its goal to break the vicious circle between the banks and the state successfully. Hungary should consider the case of ABLV in particular. Despite having a market share of $13 \%$ in the Latvian banking market and being considered as an O-SII institution, ABLV's resolution did not take place. The reason for the decision was the lack of public interest. From the point of view of Hungary, it may give rise to the argument against the Banking Union according to which, in the opinion of European decision makers, domestic banks are not significant enough to have access to the resolution fund if necessary. We should not forget that the National Bank of Hungary decided to resolve MKB in Hungary at the end of 2014. Although MKB's balance sheet total was nearly double of ABLV's balance sheet total, its market share was only about $7 \%$.

The target level of the resolution fund (EUR 55 billion) is really imposing. However, Kisgergely-Szombati (2014) raise the question whether the decision-making mechanism in the Banking Union can be as fast as in the case of its national counterpart. In the current national model, the resolution scenario has to be approved of only by the Financial Stability Board. Implementation can start immediately after the approval. The decision-making mechanism of the Banking Union requires several participants, which slows down the process. However, in the case of decisions on resolution, efficient actions are based on and depend on fastness.

Another important aspect is that joining the Banking Union would lead to the imbalance of the institutional unity of monetary policy and supervision, which would probably slow down the information flow between supervisory and mon-

20 Andrea Enria, as the Chairperson of the European Banking Authority (EBA) spoke about the decision on the resolution of Banca Popolare di Vicenza and Veneto Banca. The SRB rejected the resolution, however, the Italian state strove to provide significant government subsidies to mitigate the harmful effects of the liquidation of the two Italian banks on financial stability. Enria referred to the phenomenon as the dual interpretation of public interest (by Europe and by the Member States). (European Parliament 2017) 
etary policy functions. At the same time, during a banking crisis, it is especially important that monetary policy should receive information about the bank concerned, based on which it can consider whether it is a liquidity or a solvency crisis. A pure liquidity crisis may easily escalate into a solvency crisis if the central bank delays taking measures at the critical moment owing to the lack of the required information.

The case studies presented in Chapter 4 revealed at several points that the operation of the Banking Union is not perfect yet (e.g. the question of the supervisory authority's liability in fighting money laundering). As close cooperation can be initiated anytime, we might argue that "waiting" is a rational strategy: it is worth joining the Banking Union when several years of successful operation have proven that the theoretical benefits of the Banking Union can work in practice, as well. As far as the timing of the accession is concerned, none of the supervisory authorities of any of the Member States has concluded a close cooperation agreement with the ECB yet. In particular, considering the fact that the countries of the region have not joined the Banking Union either, the strategy of "waiting" is not a competitive disadvantage for Hungary.

According to Mérö-Piroska (2017), the high percentage of foreign ownership in the domestic banking sector can be mentioned as an argument against joining the Banking Union. The authors defined three main fields of banking policy through which the state can affect the banking system: ownership, regulation and supervision. Due to the high percentage of foreign ownership, domestic participants have only limited influence through ownership on the Hungarian banking system. In the area of regulation, the Single Rulebook is compulsory in Hungary, as well, therefore legislation can also have highly limited effect on the operation of domestic banks. According to this approach, joining the Banking Union would mean giving up the last field through which the state and the authorities representing the state can influence the Hungarian banking system. According to Mérö-Piroska (2017), it would not be compatible with the political intentions of the Hungarian government. 


\section{REFERENCES}

Agarwal, S. - Lucca, D. - Seru, A. - Trebbi, F. (2012): Inconsistent Regulators: Evidence From Banking. National Bureau Of Economic Research, Working Paper 17736 (https://www.nber.org/ papers/w17736.pdf, downloaded on 10.02.2019).

Darvas, Zsolt - Wolff, G. B. (2013): Should non-euro area countries join the single supervisory mechanism? Bruegel: Policy Contribution (https://doi.org/10.2478/danb-2013-0007).

European Commission (2015): Regulation of the European Parliament and of the Council Amending Regulation (EU) No. 806/2014 to establish a European deposit guarantee scheme (https://eurlex.europa.eu/legal-content/HU/TXT/PDF/?uri=CELEX:52015PCo586\&from=EN downloaded on 21.01.2019).

European Parliament (2017): Briefing. The orderly liquidation of Veneto Banca and Banca Popolare di Vicenza (http://www.europarl.europa.eu/RegData/etudes/BRIE/2017/602094/IPOL BRI(2017)602094_EN.pdf, downloaded on 22.03.2019).

European Council (2014): Banking Union. Conclusions of the European Council on the topic. (https://www.consilium.europa.eu/media/21535/sno4481hu14.pdf, downloded on 03.01.2019).

FinCEN (2018): Proposal of Special Measure against ABLV Bank, as a Financial Institution of Primary Money Laundering Concern (https://www.fincen.gov/sites/default/files/federal_register_notices/2018-02-13/ABLV\%20NPRM\%2O20180212\%20\%28Final\%2ofor\%20FR\%20Submission\%29. pdf, downloaded on 15.03.2019).

FSB (2018): 2018 list of global systemically important banks (G-SIBs), http://www.fsb.org/wp-content/uploads/P161118-1.pdf (downloaded on 07.03.2019).

Gerlach, S. - Schulz, A. - Wolff, G. B. (2010): Banking and sovereign risk in the euro area. Deutsche Bundesbank, Eurosystem, Discussion Paper, Series 1, Economic Studies, No 09/2010.

Hüttle, P. - Schoenmaker, D. (2016): Should the 'outs' join the European Banking Union? Bruegel: Policy Contribution, 2016/03.

Kisgergely, Kornél - Szombati, Anikó (2014): Banking Union Through Hungarian Eyes - the MNB's Assessment of a Possible Close Cooperation [Bankunió magyar szemmel - Hogyan látja az MNB a szoros együttmüködés lehetőségét?]. MNB-tanulmányok, 115.

Mérö Katalin - Piroska Dóra (2017): Banking Union and Banking Nationalism - The Hungarian Case in Central and Eastern European Context [Bankunió és banknacionalizmus - A magyar eset kelet-közép-európai kontextusban]. Politikatudományi Szemle 26(1), 135-160.

NouY, D. (2017): Gaming the rules or ruling the game? - How to deal with regulatory arbitrage (speech), (https://www.bankingsupervision.europa.eu/press/speeches/date $/ 2017 / \mathrm{html} / \mathrm{ssm}$. sp170915.en.html, downloaded on 01.03. 2019).

Schoenmaker, D. (2011): The Financial Trilemma. Economics Letters 111(1), 57-59.

Viscusi, W. K. - Vernon, J. M. - Harrington, J. E. (2000): Economics of Regulation and Antitrust. 3rd Edition, Cambridge: MIT Press.

Legislation referred to:

Regulation (EU) No. 806/2014 of the European Parliament and of the Council (https://eur-lex.europa.eu/legal-content/HU/TXT/PDF/?uri=CELEX:32014Ro806\&from=en, downloaded on 20.01.2019).

Further online sources:

Website of the European Commission: https://ec.europa.eu/info/index_en.

Website of the European Central Bank: https://www.bankingsupervision.europa.eu/home/html/ index.en.html. 
The official website of the European Union: https://europa.eu/european-union/index_hu.

Website of FCA (Financial Conduct Authority): https://www.fca.org.uk/.

Website of the FCMC (Financial and Capital Market Commission): http://www.fktk.lv/en/.

Website of Finance Latvia Association: https://www.financelatvia.eu/en/.

Website of Leta (Latvian Information Agency): http://leta.lv/eng.

Website of the National Bank of Hungary: https://www.mnb.hu/.

Nordea Annual Report (2018), https://www.nordea.com/Images/33-304448/Annual\%20Report\%20 Nordea\%2oBank\%20Abp\%202018.pdf (downloaded on 07.03.2019).

Website of Nordea: https://www.nordea.com.

Nordea press release: Why we propose to move into the Banking Union (2018.03.08), https://www. nordea.com/en/press-and-news/news-and-press-releases/news-group/2018/why-we-proposeto-move-into-the-banking-union.html, downloaded on 09.03.2019).

Website of OTP Bank: https://www.otpbank.hu/portal/hu/Maganszemelyek. 